\title{
THE CONSTRUCTION INDUSTRY IN FUNCTION OF THE RECOVERY OF THE REPUBLIC OF SERBIA ECONOMY
}

\author{
Igor Mladenovic* \\ Faculty of Economics, University of Nis, Nis, Serbia
}

\begin{abstract}
The current economic crisis has affected the level of the economic activity in many sectors of the economy. Among theorists and practitioners, the construction industry, followed by all the other industries, is increasingly said to be facing a serious crisis and to encourage its recovery of the overall economy of the Republic of Serbia. For this, the construction industry is said to be able to bear half of the economic growth of Serbia. However, taking into account the above-mentioned positions, the question is what the effects of the economic crisis on this economic sector are and what the effects of the measures imposed by the previous government of the Republic of Serbia regarding this sector were. Searching for answers to this question can to a great extent profile the answer of the current government regarding the solving of the problems in the Serbian construction industry.
\end{abstract}

Keywords: economic crisis, institutional environment, state subsidies, construction sector

JEL Classification: G01, E29, E29, D22

\section{INTRODUCTION}

The construction industry in all countries is faced with different challenges and problems. However, in countries with delayed transition, these problems and challenges have special characteristics, reflected in the specific institutional environment and a chronic lack of adequate funding. If we add the impact of the current economic crisis, it is more than evident that the challenges the construction industry is being faced with are gaining intensity. We emphasize the fact that, unlike some other sectors of the economy,

\footnotetext{
* Correspondence to: I. Mladenovic, Faculty of Economics, University of Nis, Trg kralja Aleksandra 11, 18000 Nis, Serbia; e-mail: igor.mladenovic@eknfak.ni.ac.rs
}

the construction industry of Serbia has failed to internationalize itself after 2000, even though favorable conditions for that have existed (Mladenović et al, 2012, 42). Acknowledging this fact, a survey on the situation in the construction sector in Serbia will be carried out, then the effects of the post-crisis measures of the Government of the Republic of Serbia in the sector will be presented and the measures for the recovery of the industry in Serbia will be defined. In this context, analyze the current business institutional framework for this sector of the economy, as well as consideration of institutional arrangements offered by the previous government of the Republic of Serbia to boost construction industry. Whether these measures have yielded the results, and what the situation in this economic sector is like, will be analyzed based on the 
representative sample. The premise is that the postcrisis measures of the Government of the Republic of Serbia have not yielded results. The validation of the hypotheses will be tested based on the representative sample.

The sample will consist of the companies that, in 2012, had a $5 \%$ share in the total revenue realized in the total construction activity of the Republic of Serbia. The case analysis will be carried out on the official financial statements of the companies included in the sample for the period from 2008 to 2012. The analysis of the balance sheet position, liquidity, financing, debt collection and profitability gained will be a clear insight into the impact of the current crisis in the construction sector in the Republic of Serbia. The subject analysis will show whether the measures of the previous government of the Republic of Serbia have been effective or, as many people say, they have become the cause of the insolvency and economic collapse of this economic sector. The analysis will help give recommendations for the recovery of this important economic sector.

\section{THE INSTITUTIONAL FRAMEWORK OF CONSTRUCTION ACTIVITIES IN SERBIA}

The construction activity in Serbia is a very important industry for the functioning of the economy as a whole. Generally speaking, the industry is associated with almost all areas of human endeavor. With the development of science and technology, civil engineering has become an important economic area, and is associated with over 30 economic activities. The products of the building activity are final outputs and inputs for other industries. The construction industry is an important generator of economic growth in developed as well as less developed countries (Oladinrin et al, 2012, 56). According to the data from the Chamber of Commerce of Serbia, the Serbian construction industry accounts for about 11,530 companies with about 116,760 employees. Construction contributes to the total number of companies with $13.1 \%$, while construction in the overall number of employees accounts for $11.8 \%$ (Serbian Chamber of Commerce).
Unfortunately, once one of the most expansive and propulsive export industries, the highly profitable Serbian construction industry, shares the fate of the overall economic situation in the country today. In 2013, the construction activity is carried out in a very specific institutional milieu. According to the World Bank, business environment is all but favorable for people engaged in the economic activity. Specifically, out of the 185 countries studied, Serbia is ranked as the 86th regarding the business environment for the realization of the economic activity (Doing Business 2013, 5). According to the same survey, the worst situation is in the area of securing permits for building. It is devastating to Serbia 179 place, where necessary; In Serbia, the devastating fact is that it is necessary to undergo 18 procedures and spend 269 days on average to obtain a permit to build (Doing Business 2013, 27). That is the biggest limiting factor in the construction sector in Serbia. Amongst the other weaknesses identified are: charging taxes (149th place), resolving insolvency (103rd), and the application of the treaty (103rd) (Doing Business 2013, 8). Such institutional milieu has resulted in the emergence of many problems in this business sector such as corruption, legal (in)security.

All this is a strong confirmation of the generally accepted thesis - the institutional theory that the market failures are the consequence of inefficient institutional arrangements. Therefore, it is necessary that the state should become active in the field of the adoption and implementation of the laws in the area of property rights, contract enforcement and guaranteeing the rights of foreign investors. It turns out, then, that the market is less well to the role of the state and its institutions of higher and vice versa (Leković, 2008, 161).

In addition, we are witnesses that rarely can the investor lawfully start construction regularly and in due time. This is a very fertile ground for corruption because makers of decisions on obtaining a permit to build want to take advantage of the complicated procedure for obtaining personal wealth. The fact that obtaining a permit to build lasts for a large number of days is the consequence of the fact that the Serbian administrative requirements of the parties are not decided on within the stipulated deadlines. According 
to experts, it is not uncommon for the objections to documents attached for the issuance of a permit to build by the administration to assume the title of illegality (Isailović, 2012, 13).

The legislation defining operations of the construction sector in Serbia is defined by the Law on Planning and Construction, Law on Cadaster, the Regulations on Energy Efficiency of Buildings Ordinance on the conditions, the content and method of issuing energy performance of buildings certificates. Defined by substantive law favors the illegal actions of administrative bodies, as it leaves discretion to the administrative objections may relate to any part of the project. This situation leads to the investor's legal uncertainty.

The inefficiency of the Real Estate Cadaster in resolving claims of the parties is also one of the serious problems affecting the number of investments in the construction industry. Without radical changes in this field, it is hard to remember what it is that can change for the better.

Such an institutional environment, with the current economic crisis, has created a new problem, namely a lack of funding for projects. Banks and other financial institutions are conspicuously ceased to hold the financing of construction companies because of legal loopholes favorable to debtors, which are extensively used in time of crisis. Namely, the "loopholes" of the disordered legal system have now emerged to the forefront, thus the majority of banks and other financial institutions have been affected.

Practice has proved that the bank typically used notes and non-judicial foreclosures as collateral for the execution of the debtor's liabilities. Everything had been working right until the crisis became more intense. However, when borrowers stopped paying their liabilities, banks were faced with unusual problems rendering their collateral meaningless. This is a direct result of the bad legislation defined by the Mortgage Law and the Law on Bankruptcy. This opened a complex problem of financing investment activity in this sector of the economy.

It is generally accepted that the main source of investment funding at level of individual national economies is in domestic savings. If you watched the entire production of the country reach the current consumption, it would mean complete stagnation and a lack of growth. In short, saving is a voluntary renunciation of consumption in the present in order to increase consumption in the future (Lewis, 1963, 619). It is understood that any delay in consumption means reducing the usefulness of certain goods in the future, analogous to time-shift their use (Mladenović \& Cvetanović, 2011, 144).

Domestic savings is certainly the most important source of funding for investment in almost all countries of the world. Its volume depends on the size of the gross domestic product per capita and the rate of national savings. Moreover, it can reliably be argued that these two macro aggregates are directly correlative conjunctions, or that a high level of the national income per capita implies a high savings rate and, conversely, a low level of the indicator corresponds to a low rate of savings. Since highly developed economies have a strong savings rate, then it is logical that the stronger percentage applied to a large amount of the national income per capita results in a sufficient amount of funds for the smooth financing of investment activities.

Industrially advanced countries own development as a rule-based investments financed by domestic savings . In contrast, in most developing countries, the insufficiency of domestic savings is by far the biggest problem of financing economic progress. "Especially in the poorest regions of the urgent current consumption competes with investments in the use of scarce factors. The result is too small an investment in productive capital, which is so essential for rapid economic progress" (Samuelson \& Nordahaus, 1992, 698).

Therefore, in their investments, developing countries partly financed additional savings from abroad as well. The national savings rate is largely determined by the size of the national income per capita, so it is not surprising that in countries where the size of the national per capita income is barely sufficient to meet the basic needs of the population is low. Hence, the development of these largely depends on an inflow of foreign funds. This situation is almost completely true for Serbia when it comes to the construction sector. Alternatives to foreign sources of funding are the very sources of their own construction companies. 
The sources of financing corporate enterprises can be classified into external and internal ones. Simply put, the former ones include share capital and another reinvested profit and depreciation. Because the owners of the capital invested in a company, in addition to maximizing the amount of interest and dividends to grow and develop "their" companies as a source of a future income, they will seek to reinvest a portion of profits at the expense of reducing the current dividend. Although this reasoning has a logical background, the policy distribution of the net profit on the portion of the dividend and the share of funding the future growth and development of the company (a reinvestment) is extremely complex and, as such, understandably not the object of study in this paper. In the context of the problem of financing economic activities, it should be mentioned that the role of a profit in the formation of the savings of the corporate sector, and thus the total national savings, has led some economists to attribute a profit a major role in financing economic development, which can also be subject to a justifiable challenge (Lewis, 1966, 120-121).

Serbia does not have much choice to finance its business activities in any construction activity. If there is not enough funding for the baseline economic activity, unfortunately there are no funds to finance innovative activities particularly important for the competitiveness of the economy (Mladenović et al, 2011, 571). On the one hand, it is well-known that household savings are not enough, and on the other hand, the bank-loan market is extremely expensive. The output of this situation can be seen in the sources of funding provided by the state. It is known that the two main sources of public savings, namely 1) a budget surplus of income over expenditure, i.e. the budget surplus, and 2) public companies' savings. When referring to the state revenue, we primarily mean the income tax base; while the government expenditure means all taxes, public goods and services as well as resources required to implement the program of income redistribution. The Serbian budget has been recording a surplus for many years. On the other hand, publicly-owned enterprises' savings are modest. These businesses are generally less successful than private enterprise, which is certainly one of the reasons for encouraging their privatization. Serbia Gas and Galenika are striking examples.
Considering all these circumstances, in order to save the construction industry, foreign sources of funding, as the only remaining source, are used. However, the construction sector of this country is special in that it is a source of directly used funding. From its budget, and indebting itself, the state has mobilized foreign savings. This has made the Government of the Republic of Serbia 2010th year. The following analysis will show whether the proposed actions have been correct or not as well as what their effects have been.

\section{INSTITUTIONAL SOLUTION TO SUPPORT THE CONSTRUCTION SECTOR IN SERBIA IN THE CRISIS}

Taking into account the circumstances and a difficult situation in the construction industry, the Serbian government mandated from 2008 to 2012 launched a measure to encourage this sector of the economy. These were the Law on Encouraging the Construction Industry of the Republic of Serbia in the Economic Crisis ("The Official Gazette of RS", no. 45/2010) and the Decree on Measures of Support to the Construction Industry Through Long-term Housing Loans in 2012. The first measure embodied the Law aimed to overcome the negative effects of the economic crisis in the Republic of Serbia in the field of construction, provide assistance to the local construction industry to overcome the crisis and, then, encourage its development and employ local construction companies and provide liquidity in this sector. The focus was on encouraging the development and employment of local companies engaged in the production of building materials and the retention of the existing employment levels and creating preconditions for the creation of new jobs. All of this should lead to the promotion of economic development in the Republic of Serbia.

In accordance with this legal decision, and upon proposal made by the competent ministry or the competent authorities of local self-governments, the Government determined the projects fully or partially financed from the budget of the local government, autonomous regions, or the Republic of Serbia. The intention of the legislature was to make the realization of these projects necessarily use domestic construction 
materials in proportion of at least $70 \%$ of the required building materials and installed equipment, if equipment is of the same quality products in the Republic of Serbia . Building construction and civil engineering projects, whose implementation was funded and implemented in accordance with the law analyzed, were related to schools, kindergartens, hospitals, housings, highways and other state roads, sporting objective, facilities for the purposes of carrying out activities in the field of culture and the like. It is interesting that the selection of the companies that implemented these projects led the negotiated procedure without prior notice in accordance with the law governing public procurement. In this way, the state could choose with whom to work and has the discretion of the company will benefit from this law . Also, the implementations of the Act were limited in time, and stipulated its duration until 31st December 2011, where it was concluded to a short-term measure.

Another measure taken by the Government is the Decree on Measures of Support to the Construction Industry Through Long-term Housing Loans in 2012. Its purpose was to support the construction industry through long-term housing loans and purchase, or the construction of housing units for the category of citizens who saw a solution to their housing problem in raising the credit rating and lower interest rates . For the purpose of this measure, the state opted for 1.7 billion. The beneficiaries of these subsidies were the citizens who had already resolved the issue, in which the amount of the monthly household income did not exceed 150,000 dinars. The state subsidized the participation of eligible citizens in a housing loan in the amount of $20 \%$ of the property (an interest free loan to be returned upon payment of a mortgage loan), $5 \%$ of the property being financed by the user, and $75 \%$ of the price of the housing units being financed by a business bank. These measures were very attractive, but in time of crisis, fewer people chose to use them. These measures were also short-term because the statute referred only to 2012 .

The question raised is what the effects of these measures were and whether there are companies using the proposed benefits improved its financial position . Reply to this questions looking for in the analysis of the major companies operating in the field construction before and after the introduction of these measures.

\section{AN ANALYSIS OF THE BALANCE SHEET ITEMS OF THE CONSTRUCTION SECTOR IN SERBIA IN THE 2008-2012 PERIOD}

For the purposes of this study, the sample consists of 10 companies, whose core activity is the construction of residential and non-residential buildings, which were the backbone of the economic activity in this sector of the economy. In 2012, these companies accounted for $5 \%$ of the overall income realized in the construction sector in Serbia as a whole. In 2012, the presented sample accounted for $30 \%$ of the total revenue in the construction of residential and nonresidential buildings in 2012, which is a representative sample more than evident. The sample consists of the following companies: "Užice Roads" LTD, Užice; "The Building Directorate of Serbia" LLC, Belgrade; "Energoprojekt - Construction" LTD, Belgrade; "Deneza M Engineering", Belgrade; "Inter-Kop" LLC, Šabac; "Energo Group" LLC, Belgrade; "Tehnogradnja" LLC, Kruševac, "PMC - Engineering" LLC, Belgrade; "Garden", Belgrade; "Strabag AG", Belgrade. The objective of the analysis of the Balance Sheet items was to gain an insight into what the effects of the crisis and the government's measures were on the individual items in the financial statements of the analyzed companies. The focus is primarily on the position of the total income (Graph 1).

Based on the Graph 1 data, it can be concluded that there was an evident stagnation in income from 2008 to 2010 that are implemented construction companies in Serbia. If this is added the fact that revenues are expressed in the current prices, it can be concluded that there was a decline in real incomes in this sector in the period from 2008 to 2010. That is why the previous government passed the "Law on Encouraging the Construction Industry of the Republic of Serbia During the Economic Crisis" in 2010; it is also evident that the measures gave the results. This is supported by revenue growth in 2011and 2012. The conclusion is that the analysis (of large companies) was included in the measures of the government and that they had 


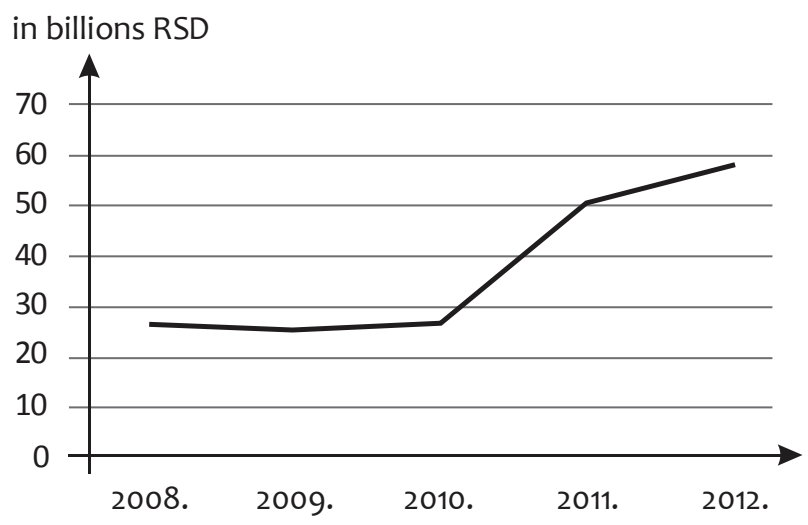

- Total revenue

Graph 1 The trend of the total revenue in the sample for the period 2008-2012

Source: Author, on the basis of the official financial statements

fulfilled all the necessary conditions prescribed by the law and posted the increased revenues. In this way, it was expected to alleviate the negative effects of the crisis on the budget of the Republic of Serbia.

A similar conclusion can be drawn if the dynamics and level of working capital in the companies analyzed (Graph 2) were analyzed. Specifically, in order to enlarge the scope of the activities implemented by the companies, a greater volume of working capital had to be engaged.

However, if the Balance Sheet position of the movement of the fixed assets is analyzed, we reach a conclusion that the measures of 2010 were short-term. Graph 3 reveals the fact that, after an increase in the volume of the fixed assets by 2011, there was a decrease in the position of the sample by 2012 .

Interestingly, a reduction in the level of the fixed assets was recorded in 7 out of the 10 analyzed companies. This leads to the conclusion that something serious had happened in their business. An analysis of financing expenses in the period answers this question (Graph $4)$.

The Graph 4 makes us conclude that the construction sector borrowed extensively in order to comply with the obligations of the contracted work. However,

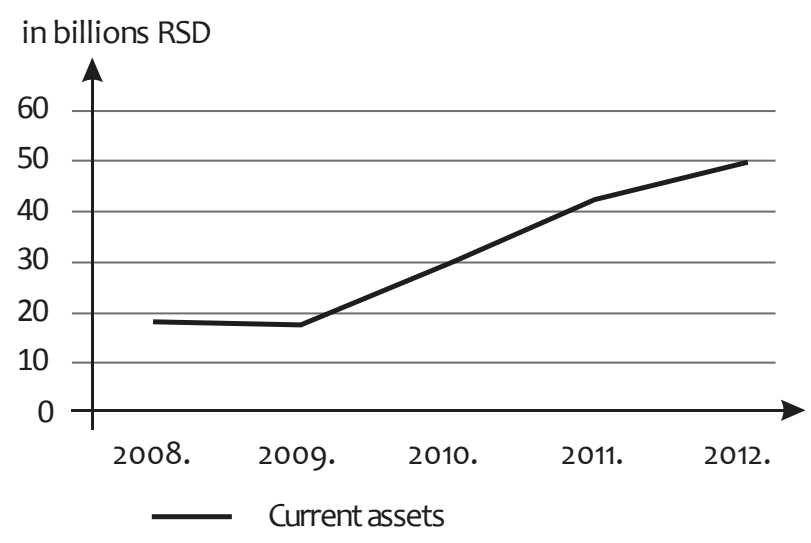

Graph 2 Movements in the level of the current assets in the sample for the period 2008-2012

Source: Author, on the basis of the official financial statements

in billions RSD

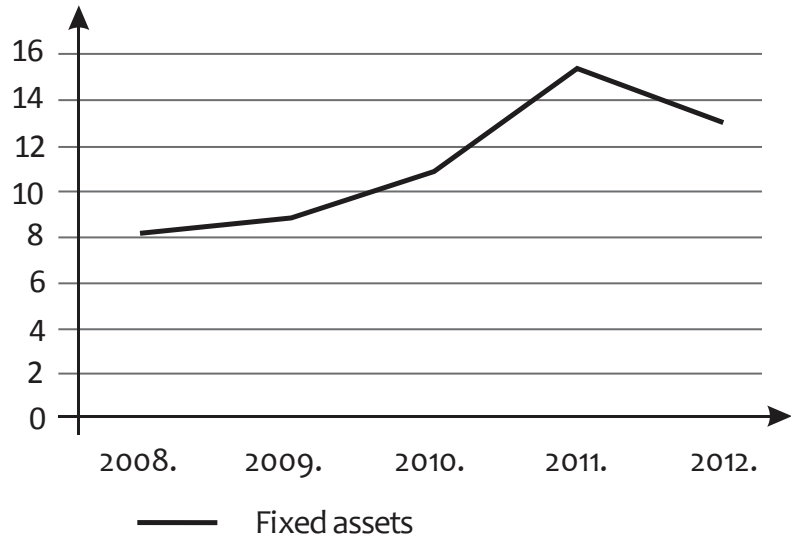

Graph 3 Movements in the level of the fixed assets in the sample for the period 2008-2012.

Source: Author, on the basis of the official financial statements

what is missing is a timely payment of the obligations of the state. In an interview with the managers of the companies, the state did not comply with the terms of payment, and the contractors had to comply with their financial obligations for an increased volume of work, which they the state assigned them. All this led to 


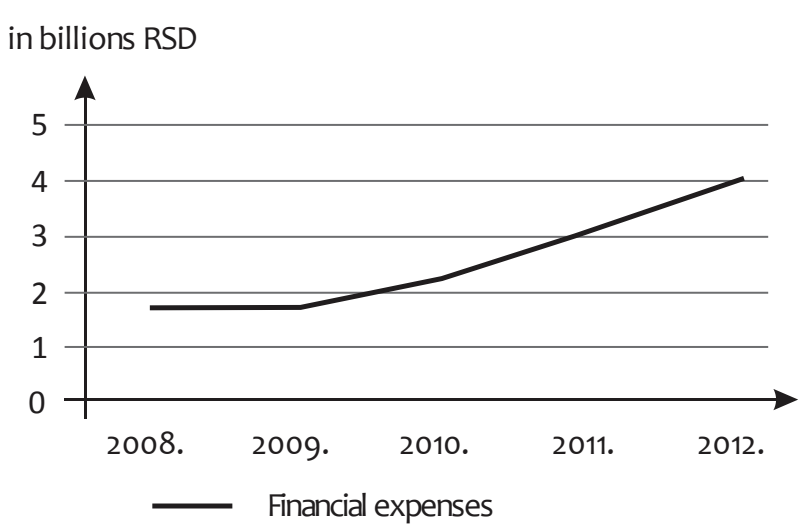

Graph 4 Movements in the level of financial expenses in the sample for the period 2008-2012

Source: Author, on the basis of the official financial statements

an increase in the share of the liabilities in financing, which is also confirmed by the Graph 5 .

The share of the liabilities in the financing of the construction companies in Serbia was in a gradual decline during 2008 and 2009. This is because, in this period, there was an investment boom in the housing

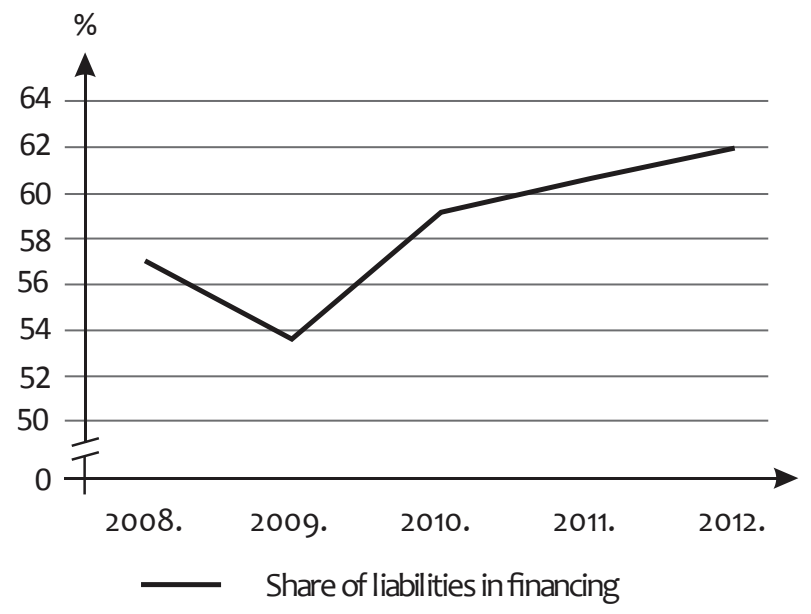

Graph 5 The share of the liabilities in financing in the sample for the period 2008-2012

Source: Author, on the basis of the official financial statements construction, and construction companies were slow in their debt repayment. It should be recalled that, in Serbia in 2008, there was the so-called "price bubble" on finished apartments in Belgrade, which was a result of the high demand on unrealistic grounds. Buying an apartment in Belgrade was a good alternative to holding cash. With the intensification of the economic crisis and its spillover in Serbia, however, those days are a distant past. This resulted in an enormous increase in the share of the liabilities in financing, namely in the higher borrowing by the construction sector. The above-mentioned developments had their repercussions on the liquidity ratios and crafts.

\section{AN ANALYSIS OF THE LIQUIDITY INDICATORS OF THE CONSTRUCTION SECTOR BETWEEN 2008 AND 2012}

Whether the effects of the crisis and the measures of the Government had their repercussions on the liquidity of this sector or can be seen based on the analysis of the current liquidity ratio. For each company in the sample, the time frame of the analysis, the calculated indicator of the current liquidity ratio and the proportion to the economic strength of the company (business income) are calculated for the sample as a whole. The results of the analysis are shown in the Graph 6.

The 2008 analysis showed that one RSD of short-term liabilities in the construction sector in Serbia was covered with 0.93 dinars of the current assets. The end of 2012 shows that 0.87 dinars of the current assets cover 1 RSD of the current liabilities. Considering that the minimum desirable level of this indicator is 1 , it is seen that, at the beginning of 2013, the liquidity of the construction sector in Serbia was seriously affected. For example, according to the data of the SBRA (Serbian Business Registers Agency), in the Serbian economy and the entire construction sector in Serbia, this indicator amounted to 1.01 and 0.9 in 2012. This confirms the representativeness of the sample and the applied methodology, as well as the fact that the construction sector is less liquid in the analyzed period, compared to the average liquidity of companies in Serbia. 


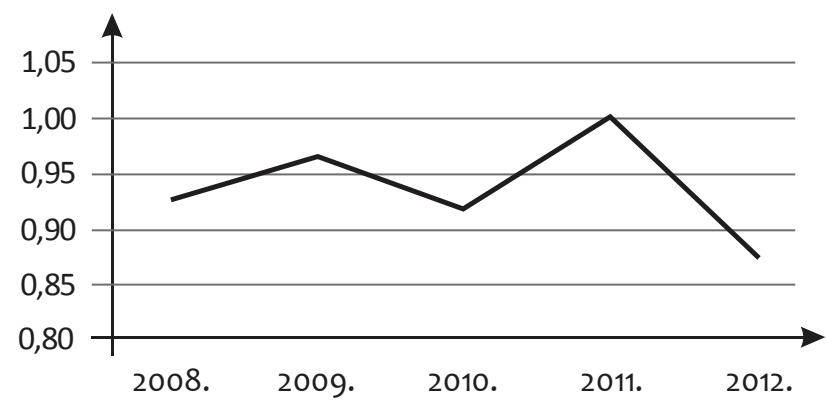

C Current liquidity ratio

Graph 6 The current liquidity ratio in the sample for the period 2008-2012

Source: Author, on the basis of the official financial statements

A similar conclusion can be made if the coefficient of debt collection (Graph 7) is analyzed.

The analysis of the debtors' turnover ratio sample shows that, in 2008, the construction sector charged their claims 68 days on average. In 2012, the debtor turnover was carried out on an average of 83 days. Interestingly, in 2009 and 2010, the values of the ratio were 3.14 and 3.16, respectively. In other words, it took nearly 114 days to collect the receivables. So, the facts in those years caused an intervention by the Government

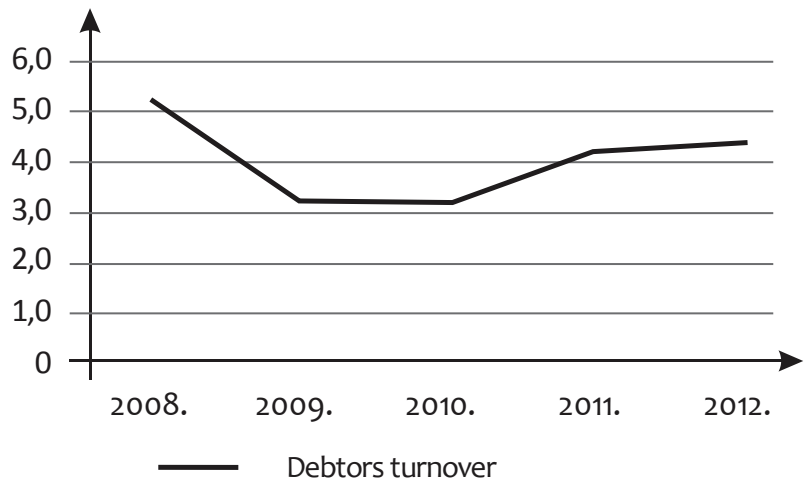

Graph 7 The trend of the current liquidity ratio of the sample for the period 2008-2012

Source: Author, on the basis of the official financial statements with respect to the mentioned Law on Incentives, but after the first analysis had been carried out, the effects were short-lived. On the pattern of Serbia (companies that file financial statements - SBRA), the average number of days for claims in the period to 2012was 78 days, while in was 109 days for all companies in the entire construction industry in Serbia in this period. This data confirms that the analyzed sample is fully representative and describes the true picture of the sector in Serbia. The question posed is what the effects on the key indicators of the business performance of companies in the field of construction in Serbia are in the period analyzed.

\section{AN ANALYSIS OF THE INDICATORS OF SUCCESS IN THE CONSTRUCTION SECTOR IN SERBIA FROM 2008 TO 2012}

The analysis of the business performance of the construction sector in Serbia is seen through the main three economic indicators. These include: EBITDA, the total revenue in the total expenses ratio, and return on assets. For each company in the sample, it was calculated during the period, by the values of these parameters, and the indicator was calculated for the sample as a whole on the basis of the economic strength of each company . Criteria for the economic strength of any share in the revenue.

EBITDA, i.e. Earnings before interest, taxes, depreciation and amortization, represents earnings of a company, excluding - however - taxes, an interest, depreciation and amortization in the calculation of a profit. Many people referred to EBITDA as earnings before all the bad stuff and the term is used to analyze and compare profitability between different economic sectors of an economy or society. Another reason lies in the fact that the calculation of this indicator excludes the effects of financing and accounting decisions, which are individual to each enterprise. This indicator emphasizes the ability of a company to realize a profit from its core activities.

The analysis of EBITDA confirms what has been discussed so far. From 2008 to 2010, a decline in EBITDA was recorded. The 2010 Government measures yielded 
short-term improvements, when an increase in the value of this ratio was recorded in 2011 only to have its value reduced in as soon as 2012. In an interview with the managers of the companies analyzed, the cause for the rise was the cost of doing business, especially financial expenses, and desisting from the activities ordered by the state, because it was not good "payer" (Graph 8).

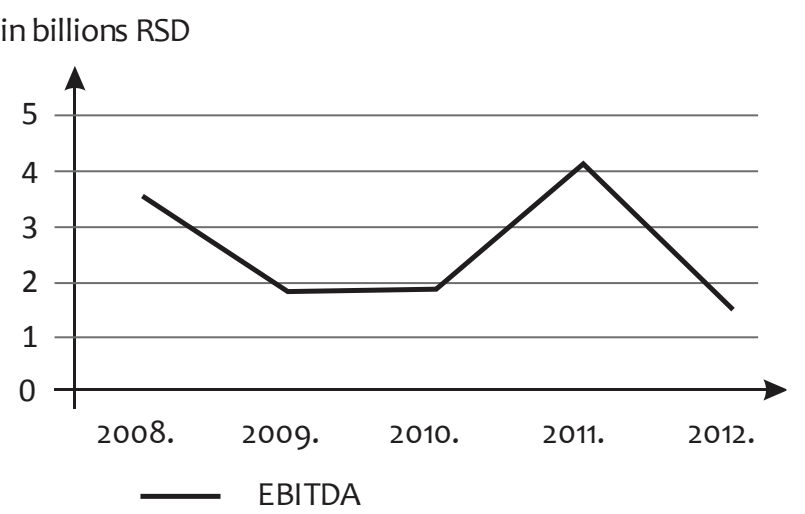

Graph 8 Movements in EBITDA in the sample for the period 2008-2012

Source: Author, on the basis of the official financial statements

Effectiveness as a total revenue and total expenses ratio is an important indicator of the economic success of a business. Although the preferred minimum value of this ratio is one, the survey has shown the value of this ratio below one (Graph 9). This shows that the residential-and-non-residential-building construction sector is insufficiently successful in doing business. For example, at the level of the country as a whole (the companies filing their financial statements with the BRA), the value of this indicator was 1.01 in 2012, whereas it was 0.9 for the Serbian overall construction activity. This is only a confirmation of the fact that the sample in this study is representative and that it provides us with the current situation in the construction sector in Serbia. The analysis of the sample shows a permanent reduction in the value of this indicator from 2010 to date. The situation is particularly alarming for 2012, when the value of all

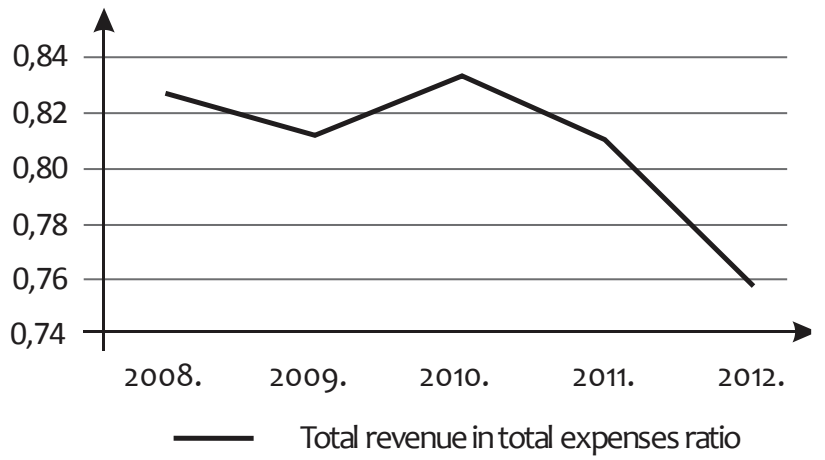

Graph 9 The total revenue in total expenses ratio in the sample for the period 2008-2012

Source: Author, on the basis of the official financial statements

revenues only covered $76 \%$ of the total expenditure in the analyzed sample.

ROA (return on assets) shows the earning ability of a company. For the analyzed sample, the value of this ratio is intensively falling, particularly during 2012, when one of the largest companies in the sample had an entirely negative net profit. This indicates that the companies engaged property in the field of building a modest earning ability. The yield was $6 \%$ in 2008, and has been decreasing ever since then (Graph 10).

In order to verify the representativeness of the sample and analyze the data obtained from the SBRA, it was discovered that for the overall Serbian construction industry in 2012, the value of this indicator was $-2.34 \%$. This has again confirmed the fact that the construction activity in Serbia is in a serious crisis and that on average one RSD of the assets involved in this sector realizes an average loss of 0.023 RSD . In comparison to Serbia as a whole (all companies filing their financial statements), the value of this ratio is $0.19 \%$. In other words, the average Serbian company generates a net profit of 0.0019 RSD on one RSD of assets. This is an extremely low value of this indicator. As we have seen, the construction sector, as part of the economy, has the above-mentioned results.

This analysis has shown that when the construction sector in Serbia is concerned, the measures imposed by the state intervention gave short-term results. It is also 


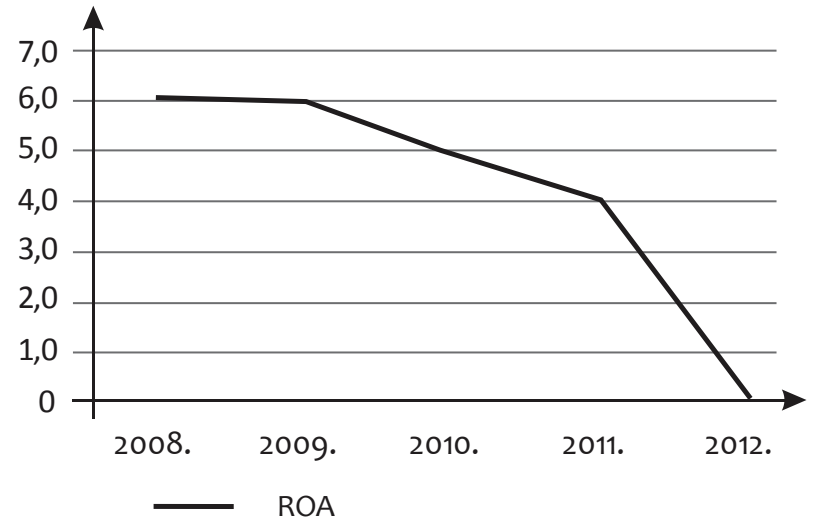

Graph 10 ROA Movements in \% for the sample period 2008-2012

Source: Author, on the basis of the official financial statements

evident that the measures had elements of a classic state failure. Not a small number of papers in Serbia are indicative of this fact. The "analysis of the failure of the state, first at the theoretical and methodological levels and then from the perspective of the functioning of the national economy, should serve the as a relevant source of information for an economic policy and the creation of a market economy" (Petrović, 2013, 16). If policy makers in Serbia were aware of these shortcomings, the conditions for the adoption of appropriate measures by which to perceive the effectiveness and efficiency of subsidized company-specific government activities. Perhaps some solutions related to publicprivate partnerships in this area stand for a good basis for thinking the future (Suhaiza, 2013, 98).

\section{CONCLUSION}

The business analysis of the construction sector in Serbia conducted over the past five years has shown this sector of the economy to be having serious problems. It unequivocally demonstrated that the problems are due to several factors. The first factor is the poor institutional environment for dealing with this sector of the economy, which is reflected in the option open to legal arrangements in place for the safety of the epilogue was legal uncertainty. This institutionalized framework is a good ground for corruption as the biggest systemic problem of the Serbian society. The second one, the inadequate sources of funding for this very specific branch of the economy and an inadequate response to the third state in stimulating this sector of the economy in terms of the current economic crisis. A survey confirmed that these factors have contributed to deterioration in the liquidity construction activities even to $10 \%$ below the already poor liquidity levels of Serbian companies. That is inadequately designed to help this sector of the economy affected by the "darlings" of the previous government are inadequate indicators of business success, especially in the area of return on assets, which had a negative value for 2012. Overall, the study confirms the initial hypothesis that the effects of the government intervention were of a short duration and that in one segment of the cause for the poor condition of this sector of the Serbian economy . In this way, the survey shows that the construction industry should be designed by structural measures to help the sector begin to recover. A systematic approach means that, in addition to direct financial incentives, many far-reaching effects can be measured in the changes of the institutional environment, which the sector operates in. The research has just opened this issue, and sometimes it is a good and important question for the sake of seeking an adequate response.

\section{REFERENCES}

Isailović, I. (2012). Propast građevinske industrije. Profit, decembar 2011 / januar 2012, 12-13.

Leković, V. (2001). Korelacija tržišne institucionalizacije i tranzicionih procesa. Ekonomski horizonti, 1-2, 31-42.

Lewis, A. (1963). Economic Development with Unlimited Supplies of Labor: The Economics of Underdevelopment. New York.

Lewis, A. (1966). Development Planing. London, UK: G. Allen.

Mladenović, I. i Cvetanović, S. (2011). Kapital u teoriji rasta $i$ razvoja, Niš, Ekonomski fakultet Univerziteta u Nišu.

Mladenović, I., Ćuzović, S., \& Sokolov, S. (2012). Business performances of the Serbian trade sector in conditions of internationalization. Industrija, 40(4), 41-62.

Mladenović, I., Stanković, Lj., Đukić, S., i Popović, A. (2011). Unapređenje poslovne konkurentnosti preduzeća zasnovano na inovacijama. Ekonomske teme, 4, 559-580. 
Oladinrin, T., Ogunsemi, D., \& Aje, I. (2012). Role of Construction Sector in Economic Growth: Empirical Evidence from Nigeria. FUTY Journal of the Environment, 7(1), 50-60.

Patricia, M. H. (1974). Economic Theory and the Construction Industry. MacMillan Press.

Petrović, D. (2013). Ključni teorijski i praktični aspekti državnih neuspeha u savremenoj ekonomiji. Ekonomski horizonti, 15(2), 149-161.

Privredna komora Srbije. Privreda Srbije. dostupno na http:/ www.pks.rs/PrivredaSrbije.aspx?id=7\&p=2\&

Samuelson, P., \& Nordahaus, W. (1992). Ekonomija. Zagreb, Hrvatska: Mate.

Službeni glasnik RS, 45/2010.

Suhaiza, I. (2013). Factors attracting the use of public private partnership in Malaysia. Journal of Construction in Developing Countries, 18(1), 95-108.

The International Bank for Reconstruction and Development / The World Bank, Doing Business 2013, dostupno na http:// www.doingbusiness.org/ /media/giawb/doing\%20business/ documents/profiles/country/SRB.pdf

Uredba o merama podrške građevinskoj industriji kroz dugoročno stambeno kreditiranje u 2012.
Zvanični finansijski izveštaji od 2008. do 2012. A.D. "Putevi Užice", Užice.

Zvanični finansijski izveštaji od 2008. do 2012. "Građevinska Direkcija Srbije" d.o.o Beograd.

Zvanični finansijski izveštaji od 2008. do 2012. A.D. "Energoprojekt - visokogradnja", Beograd.

Zvanični finansijski izveštaji od 2008. do 2012. "Deneza M Inženjering" d.o.o, Beograd.

Zvanični finansijski izveštaji od 2008. do 2012. "Inter-Kop" d.o.o., Šabac.

Zvanični finansijski izveštaji od 2008. do 2012. "Energo group" d.o.o., Beograd.

Zvanični finansijski izveštaji od 2008. do 2012. "Tehnogradnja" d.o.o., Kruševac.

Zvanični finansijski izveštaji od 2008. do 2012. "PMC Inženjering" d.o.o. Beograd.

Zvanični finansijski izveštaji od 2008. do 2012. "Gradina" d.o.o., Beograd.

Zvanični finansijski izveštaji od 2008. do 2012. "AG Strabag", Beograd.

Igor Mladenovic is an associate professor at the Faculty of Economics, University of Nis. He received his $\mathrm{PhD}$ degree in the field of the role institutional investors in financing of economic development. $\mathrm{He}$ teaches the subjects: Macroeconomics and Theory and Policy of Economic Development. 


\title{
GRAĐEVINARSTVO KAO INDUSTRIJSKI SEKTOR U FUNKCIJI OPORAVKA PRIVREDE REPUBLIKE SRBIJE
}

\author{
Igor Mladenović \\ Ekonomski fakultet Univerziteta u Nišu
}

\begin{abstract}
Aktuelna ekonomska kriza uticala je na nivo ekonomske aktivnosti u mnogim sektorima privređivanja. Među teoretičarima i ljudima iz prakse sve se češće čuje stav da je građevinarstvo kao industrijski sektor, koji prate sve druge privredne grane, $\mathrm{u}$ ozbiljnoj krizi i da bi njegov oporavak podstakao oporavak ukupne privrede Republike Srbije (RS). Za ovu industrijsku granu se kaže da može da nosi polovinu privrednog rasta unutar RS. Međutim, uz uvažavanje pomenutih stavova, postavlja se pitanje o tome kakvi su efekti ekonomske krize na ovaj privredni sektor i kakvi su bili efekti mera prethodne Vlade RS u ovom sektoru. Traženje odgovora na ovako postavljeno pitanje umnogome može da profiliše odgovor aktuelne Vlade RS za rešavanje problema u građevinskoj industriji RS.
\end{abstract}

Ključne reči: građevinarstvo, institucionalno okruženje, državne subvencije, privredni oporavak

\section{UVOD}

Građevinska industija u svim zemljama susreće se sa različitim izazovima i problemima. Međutim, $u$ zemljama sa zakasnelom tranzicijom ti problemi i izazovi imaju svoje specifičnosti koje se ogledaju u posebnom institucionalnom ambijentu i hroničnom nedostatku adekvatnih izvora finansiranja. Ukoliko ovome dodamo i uticaj aktuelene ekonomske krize, više je nego evidentno da izazovi pred građevinskom industijom dobijaju na intenzitetu. Posebno naglašavamo da, za razliku od nekih drugih sektora privređivanja, građevinska industrija Republike

\footnotetext{
* Korespondencija: I. Mladenović, Ekonomski fakultet Univerziteta u Nišu, Trg kralja Aleksandra 11, 18000 Niš, Srbija; e-mail: igor.mladenovic@eknfak.ni.ac.rs
}

Srbije (RS), nije uspela da se nakon 2000. godine internacionalizuje, iako su za to postojali povoljni uslovi (Mladenović, I. i ostali, 2012, 42).

Uvažavajući ove činjenice, $u$ radu će biti istraženi stanje građevinskog sektora u RS i efekti postkriznih mera Vlade Republike Srbije $\mathrm{u}$ ovom sektoru, u kontekstu definisanja mera za oporavak ove industrijske grane u RS. U ovom kontekstu analiziraće se aktuelni institucuionalni okvir poslovanja ovog sektora privrede, kao i sagledavanje ponuđenih institucionalnih rešenja od strane prethodne Vlade Republike Srbije za podsticaj građevinske industrije. Da li su te mere dale rezultate i kakvo je stanje $\mathrm{u}$ ovom sektoru privrede analiziraćemo na bazi reprezentativnog uzorka.

Polazna hipoteza jeste da postkrizne mere Vlade Republike Srbije nisu dale rezultate. Validnost 
postavljene hipoteze testiraćemo na bazi reprezentativnog uzorka.

Uzorak čine firme koje su u 2012. godini učestvovale sa $5 \%$ u ukupnom prihodu koji je realizovan u ukupnoj građevinskoj delatnosti RS. Predmet analize biće zvanični finansijski izveštaji privrednih društava koja čine uzorak u periodu od 2008. do 2012. godine. Analizom bilansnih pozicija, pokazatelja likvidnosti, finansiranja, naplate potraživanja i profitabilnosti stekao bi se jasan uvid u uticaj aktuelne krize na građevinski sektor RS. Predmetna analiza bi pokazala da li su mere prethodne Vlade Republike Srbije bile efikasne ili su pak, kako mnogi tvrde, postale uzrok nelikvidnosti i ekonomskog kolapsa ovog sektora privređivanja. Analiza će pomoći da se daju i preporuke za oporavak ovog izuzetno važnog sektora privrede.

\section{INSTITUCIONALNI OKVIR POSLOVANJA GRAĐEVINSKOG SEKTORA U REPUBLICI SRBIJI}

Građevinska delatnost u RS je izuzetno značajna privredna grana za funkcionisanje privrede $\mathrm{u}$ celini. Generalno govoreći, ova privredna grana je povezana sa gotovo svim oblastima ljudskog delovanja. Razvojem nauke i tehnike, građevinarstvo je postalo značajna privredna oblast, povezana sa preko 30 privrednih delatnosti. Proizvodi građevinske dealtnosti su inputi za druge privredne grane. Građevinska industrija je važan generator privrednog rasta $u$ razvijenim, ali i u manje razvijenim zemljama (Oladinrin et al, 2012, 56). Prema podacima Privredne komore Srbije, građevinsku delatnost RS čini oko 11.530 privrednih društava, sa oko 116.760 radnika. Građevinarstvo učestvuje $\mathrm{u}$ ukupnom broju privrednih društava sa 13,1\% dok građevinarstvo učestvuje u ukupnom broju zaposlenih sa 11,8\% (Privredna komora Srbije).

Nažalost, nekada jedna od najekspanzivnijih i najpropulzivnijih izvoznih privednih grana, profitabilno i visoko akumulativno srpsko građevinarstvo danas deli sudbinu ukupne privredne situacije u zemlji. U 2013. godini građevinska delatnost posluje u veoma specifičnom institucionalnom miljeu.
Samo poslovno okruženje, prema podacima Svetske banke, nije baš naklonjeno ljudima koji se bave privrednom aktivnošću. Naime, od 185 istraživanih zemalja, po poslovnom ambijentu za realizaciju privrednih aktivnosti, RS je na 86. mestu (Doing Business 2013, 5). Prema istom istraživanju najlošija situacija je u oblasti obezbeđivanja građevinskih dozvola. Tu je Srbija na poražavajućem 179. mestu, gde je potrebno sprovesti 18 procedura i u proseku 269 dana za dobijanje građevinske dozvole. (Doing Business 2013, 27). Ovo ujedno predstavlja najveći ograničavajući faktor za sektor građevinarstva u RS. Ostale slabosti koje su identifikovane su naplata poreza 149. mesto, rešavanje bankrotstava 103. i primena ugovora, takođe, 103. mesto (Doing Business 2013, 8). Ovakav institucionalni milje imao je za posledicu pojavu brojnih problema u ovom sektoru privređivanja, kao što su korupcija, pravna (ne)sigurnost, itd.

Sve ovo je potvrda opšteprihvaćene teze neoinstitucionalne teorije da su tržišni nedostaci posledica neefikasnog institucionalnog uređenja. Zato je potrebno da se država aktivira na planu donošenja i primene zakona u oblasti zaštite svojine, sprovođenja ugovora i garantovanja prava stranih investitora. Ispostavlja se, dakle, da što je tržište manje savršeno, to je uloga države i njenih institucija veća, i obratno (Leković, 2001, 39).

Dodatno, svedoci smo da je prava retkost da investitor redovnim putem, $\mathrm{u}$ dogledno vreme, zakonito može da započne izgradnju objekta. Ovo je izuzetno pogodno tlo za korupciju, jer oni koji odlučuju o dobijanju građevinske dozvole žele da komplikovanu proceduru iskoriste za sticanje ličnog bogatstva. Veliki broj dana za izdavanje građevinske dozvole jeste posledica toga da srpska administracija o zahtevima stranaka ne odlučuje u okviru predviđenih rokova. Po mišljenju stručnjaka, nije redak slučaj da primedbe na priloženu dokumentaciju za izdavanje građevinske dozvole, od strane administracije, poprimaju epitet nezakonitosti (Isailović, 2012, 13).

Pravna regulativa koja definiše poslovanje građevinskog sektora u RS definisana je Zakonom o planiranju i izgradnji, Zakonom o državnom premeru i katastru, Pravilnikom o energetskoj efikasnosti zgrada, Pravilnikom o uslovima, sadržini i načinu 
izdavanja sertifikata o energetskim svojstvima zgrada. Definisano materijalno pravo pogoduje nezakonitom postupanju organa uprave, jer ostavlja diskreciono ovlašćenje administraciji da primedbe mogu da se odnose na bilo koji deo projekta. Ovakva situacija vodi ka pravnoj nesigurnosti investitora.

Neefikasnost Katastra nepokretnosti u rešavanju zahteva stranaka je, takođe, jedan od ozbiljnih problema, koji utiču na broj investicija u građevinskoj industriji. Bez korenitih promena u ovoj oblasti, teško da se išta nabolje može promeniti.

Ovakav institucionalni ambijent, uz aktuelnu ekonomsku krizu, otvorio je novi problem, a to je nedostatak sredstava za finansiranje projekata. Banke i druge finansijske organizacije su prestale da finansiraju građevinske firme zato što pravne praznine pogoduju dužnicima, koji to u uslovima krize obilato koriste. Naime, "rupe“ neuređenog pravnog sistema sada su izašle u prvi plan i na najvećem udaru su se upravo našle banke i druge finansijske organizacije.

Praksa je pokazala da su banke kao sredstvo obezbeđenja izvršenja dužnikove obaveze obično koristile menice i vansudske hipoteke. Sve je funkcionisalo $u$ najboljem redu dok kriza nije dobila na intenzitetu. Međutim, kada su dužnici prestali da izmiruju svoje obaveze, banke su počele da se susreću sa problemima koji su obesmišljavali njihova sredstva obezbeđenja. Ovo je direktna posledica loših zakonskih rešenja definisanih Zakonom o hipoteci i Zakonom o stečaju. Ovo je otvorilo složenu problematiku finansiranja investicionih aktivnosti u ovom sektoru privrede.

Opšte je prihvaćen stav da je osnovni izvor finansiranja investicija na nivou pojedinih nacionalnih ekonomija domaća štednja. Kad bi se celokupna proizvodnja posmatrane zemlje plasirala u tekuću potrošnju, to bi značilo potpunu stagnaciju i nemogućnost privrednog rasta. Najkraće, štednja predstavlja dobrovoljno odricanje potrošnje $u$ sadašnjosti $u$ cilju veće potrošnje u budućnosti (Lewis, 1963, 619). Razumljivo da svako odlaganje potrošnje podrazumeva smanjenje korisnosti pojedinih dobara u budućnosti, analogno pomeranju vremena njihovog korišćenja (Mladenović i Cvetanović, 2011, 144).
Domaća štednja je svakako najvažniji izvor finansiranja investicija $u$ skoro svim zemljama sveta. Njen obim zavisi od veličine bruto domaćeg proizvoda po stanovniku i od stope nacionalne štednje. Štaviše, pouzdano se može tvrditi da se ova dva makroagregata nalaze $u$ direktnoj korelacionoj sprezi, odnosno, da visok nivo nacionalnog dohotka per capita podrazumeva visoku stopu štednje i, obratno, nizak nivo tog pokazatelja korespondira sa niskom stopom štednje. Budući da visoko razvijene privrede imaju izraženiju stopu štednje, logično je da izraženiji procenat primenjen na veliki iznos nacionalnog dohotka po stanovniku ima za posledicu dovoljnu sumu sredstava za nesmetano finansiranje investicionih aktivnosti.

Industrijski napredne zemlje svoj razvoj, po pravilu, zasnivaju na investicijama koje finansiraju domaćom štednjom. Suprotno, $\mathrm{u}$ većini zemalja u razvoju daleko najveći problem finansiranja ekonomskog napredovanja predstavlja nedovoljnost domaće štednje. „Posebno u najsiromašnijim regionima hitna tekuća potrošnja takmiči se sa investicijama kod upotrebe oskudnih faktora. Rezultat su premalene investicije u proizvodni kapital koji je tako neophodan za brz ekonomski napredak" (Samuelson \& Nordahaus, 1992, 698). Zbog toga, zemlje u razvoju svoje investicije delom finansiraju i dopunskom štednjom iz inostranstva. Stopa nacionalne štednje dobrim delom je određena veličinom nacionalnog dohotka po stanovniku, pa ne čudi što je u zemljama u kojima je veličina nacionalanog dohotka per capita jedva dovoljna da zadovolji egzistencijalne potrebe stanovništva ona niska. Otuda, razvoj u njima uveliko zavisi od priticanja inostranih sredstava. Ovakva situacija gotovo da u potpunosti važi za RS, kada je u pitanju građevinski sektor. Alternativa za inostrane izvore finansiranja jesu vlastiti izvori samih građevinskih kompanija.

Vlastiti izvori u finansiranju korporativnog preduzeća se mogu razvrstati na: eksterne i interne. Najjednostavnije rečeno, $u$ prve spada akcionarski kapital, a u druge reinvestirani profit i amortizacija. Budući da su vlasnici kapitala uloženog u neko preduzeće pored maksimizacije iznosa dividendi zainteresovani i za rast i razvoj "svog" preduzeća kao izvora budućih prihoda oni će nastojati da jedan deo 
profita reinvestiraju na račun smanjenja aktuelnih dividendi. Premda ovakvo razmišljanje ima svoju logičku pozadinu, politika raspodele neto profita na deo za dividende i deo za finansiranje budućeg rasta i razvoja preduzeća (reinvestiranje) je krajnje kompleksna i, kao takva, nije predmet proučavanja $\mathrm{u}$ ovom radu. $\mathrm{U}$ kontekstu problematike finansiranja privrednih aktivnosti treba pomenuti da je uloga profita u formiranju štednje sektora privrede, a time i ukupne nacionalne štednje navela neke ekonomiste da profitu pripišu glavnu ulogu u finansiranju privrednog razvoja, što, takođe, može biti predmet opravdanih osporavanja (Lewis, 1966, 120-121).

Građevinska delatnost RS nema mnogo izbora za finansiranje svojih privrednih aktivnosti. Ako nema dovoljno za finansiranje osnovnh privrednih aktivnosti, nažalost nema ni sredstava za finansiranje inovacionih aktivnosti koje su posebno važne za konkurentnost ovog sektora privrede (Mladenović i ostali, 2011, 571). Poznato je da štednja domaćinstava nije dovoljna, a, s druge strane, tržište bankarskih kredita je izuzetno skupo. Izlaz iz ovakve situacije mogu da budu izvori finansiranja koje obezbeđuje država. Dva su osnovna izvora javne štednje: 1) višak budžetskih prihoda nad rashodima tj. budžetski suficit i 2) štednja javnih preduzeća. Kad se kaže državni prihod, misli se, pre svega, na prihod po osnovi oporezivanja, dok se pod državnim rashodom podrazumevaju sva davanja, javna dobra i usluge, kao i sredstva neophodna za realizaciju programa redistribucije dohotka. Srpski budžet već duži niz godina ne beleži suficit. S druge strane štednja preduzeća $u$ javnom vlasništvu je skromna. Ta preduzeća uglavnom posluju manje uspešno od privatnih preduzeća, što je svakako jedan od razloga za podsticaj njihove privatizacije. Eklatantni primeri su Srbijagas i Galenika.

Uvažavajući sve ove okolnosti, za potrebe spasa građevinske industrije korišćen je inostrani izvor finansiranja, kao jedini preostali izvor. Međutim, naš građevinski sektor je specifičan po tome što je ovaj izvor finansiranja posredno korišćen. Naime, država je iz budžeta, svojim zaduživanjem mobilisala inostranu štednju. To je učinila Vlada Republike Srbije 2010. godine.

\section{INSTITUCIONALNA REŠENJA ZA PODRŠKU GRAĐEVINSKOG SEKTORA U SRBIJI U USLOVIMA KRIZE}

Uvažavajući okolnosti i teško stanje u građevinskoj industriji Srbije, Vlada Republike Srbije sa mandatom od 2008. do 2012. godine pokrenula je mere za pospešivanje ovog sektora privrede. To su bili Zakon o podsticanju građevinske industrije Republike Srbije u uslovima ekonomske krize ("Sl. glasnik RS", br. 45/2010) i Uredba o merama podrške građevinskoj industriji kroz dugoročno stambeno kreditiranje $u$ 2012. godini. Prva mera oličena Zakonom imala je za cilj da se prevaziđu negativni efekti ekonomske krize u Republici Srbiji u oblasti građevinarstva, odnosno, pruži pomoć domaćoj građevinskoj industriji za izlazak iz krize. Zatim, da se podstakne razvoj i uposle domaće građevinske firme i obezbedi likvidnost ovog sektora. Fokus je bio i na podsticanju razvoja i upošljavanju domaćih preduzeća koja se bave proizvodnjom građevinskog materijala i zadržavanje postojećeg nivoa zaposlenosti i stvaranje preduslova za otvaranje novih radnih mesta. Sve ovo je trebalo da vodi ka podsticanju privrednog razvoja u Republici Srbiji.

U skladu sa ovim zakonskim rešenjem, Vlada, na predlog nadležnih ministarstava, odnosno, nadležnog organa lokalne samouprave, utvrđivala je projekte koji su se u celosti ili delimično finansirali iz sredstava budžeta lokalne samouprave, autonomne pokrajine, odnosno, Republike Srbije. Intencija zakonodavca je bila da se, pri realizaciji ovih projekata, mora koristiti domaći građevinski materijal u učešću od najmanje $70 \%$ od ukupno potrebnog građevinskog materijala i ugrađene opreme, ukoliko se oprema istog kvaliteta proizvodi u Republici Srbiji. Projekti za izgradnju objekata visokogradnje i niskogradnje, čija se realizacija finansirala i realizovala u skladu sa analiziranim Zakonom, odnosili su se na škole, obdaništa, bolnice, stanove, autoputeve i druge državne puteve, sportske objekte, objekte za potrebe obavljanja delatnosti iz oblasti kulture i sl. Interesantno je da se za izbor firmi koje realizuju ove projekte vodio pregovarački postupak bez objavljivanja javnog poziva u skladu sa zakonom kojim se uređuju javne nabavke. $\mathrm{Na}$ taj način je država mogla da bira sa kim će da radi i da ima diskreciono pravo koje će firme imati koristi 
od ovog Zakona. Takođe, sama primena Zakona je bila vremenski ograničena, odnosno propisano je njegovo važenje do 31. decembra 2011, na osnovu čega se zakuljučuje da je reč o kratkoročnoj meri.

Druga mera koja je preduzeta od strane Vlade jeste Uredba o merama podrške građevinskoj industriji kroz dugoročno stambeno kreditiranje u 2012. godini. Cilj ove Uredbe bio je podrška građevinskoj industriji kroz dugoročno stambeno kreditiranje i kupovina, odnosno, izgradnja stambenih jedinica kategoriji građana kojima je rešavanje stambenog pitanja najvažnije, kroz podizanje kreditne sposobnosti i smanjenje kamatne stope. Za potrebe realizacije ove mere, država je u 2012. godini opredelila 1,7 milijardi dinara. Korisnici ovih subvencija bili su građani koji nemaju rešeno stambeno pitanje i u čijem domaćinstvu iznos mesečnih prihoda nije prelazio 150.000 dinara. Država je subvencionisala učešće za stambeni kredit građanima koji ispunjavaju uslove $\mathrm{u}$ vrednosti od $20 \%$ od cene nekretnine (beskamatni kredit koji se vraćao nakon otplate stambenog kredita), $5 \%$ od cene nekretnine finansirali su korisnici, a $75 \%$ vrednosti cene stambene jedinice finansirala je poslovna banka. Ove mere bile su izuzetno atraktivne, ali u vreme krize manji broj ljudi se opredelio da ih koristi. Takođe, i ove mere bile su kratkoročne, jer se Uredba odnosila samo na 2012. godinu.

Pitanje koje se nametnulo jeste kakvi su bili efekti ovih mera i da li su privredna društva koja su koristila predložene benefite poboljšala svoj finansijski položaj. Odgovor na ova pitaja tražimo $u$ analizi poslovanja značajnijih privrednih društava iz oblasti građevine pre i posle uvođenja ovih mera.

\section{ANALIZA BILANSNIH POZICIJA GRAĐEVINSKOG SEKTORA U RS U PERIODU 2008. DO 2012.}

Za potrebe ovog rada, uzorak čini 10 preduzeća čija je delatnost izgradnja stambenih i nestambenih objekata, koja su bila okosnica ekonomskih aktivnosti u ovom sektoru privrede. Te kompanije su u 2012. godini učestvovale sa $5 \%$ u ukupnom prihodu koji je realizovan $u$ sektoru građevine $u$ RS. Predmetni uzorak, samo u sektoru izgradnje stambenih i nestambenih objekata učestvuje sa 30\% ukupnog prihoda u 2012. godini, čime je reprezentativnost uzorka više nego evidentna. Uzorak čine sledeća privredna društva: A.D. „Putevi Užice”, Užice; "Građevinska Direkcija Srbije” d.o.o Beograd; A.D. „Energoprojekt - visokogradnja”, Beograd; „Deneza M Inženjering” d.o.o, Beograd; "Inter-Kop” d.o.o., Šabac; „Energo group” d.o.o., Beograd; „Tehnogradnja” d.o.o., Kruševac; „PMC - Inženjering” d.o.o. Beograd; "Gradina" d.o.o., Beograd; "AG Strabag”, Beograd. Cilj analize bilansnih pozicija jeste da se vidi kakvi su bili efekti krize i mera Vlade na pojedine stavke u finansijskim izveštajima analiziranih privrednih društava. Fokus je najpre na poziciji ukupnih prihoda (Grafikon 1).

Na osnovu podataka sa Grafikona 1 može se zaključiti da je od 2008. do 2010. godine bila evidentna stagnacija $\mathrm{u}$ prihodima koje su realizovala građevinska preduzeća u Srbiji. Ako se ovome doda činjenica da su prihodi izraženi u tekućim cenama, može se zaključiti da je u periodu od 2008. do 2010. došlo do pada realnog prihoda u ovom sektoru. Zato je i prethodna Vlada donela Zakon o podsticanju građevinske industrije Republike Srbije u uslovima ekonomske krize u 2010. godini i evidentno je da su mere dale rezultate. To

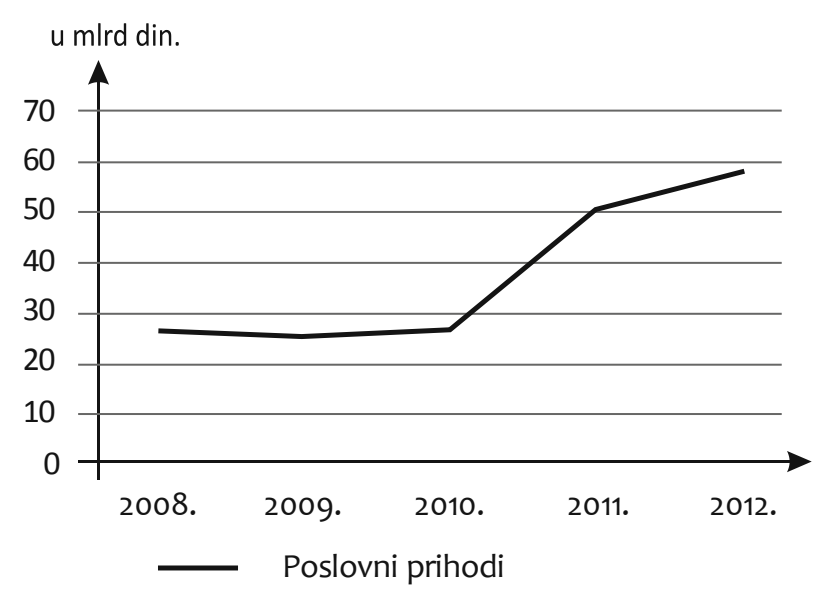

Grafikon 1 Kretanje ukupnih prihoda u uzorku za period 2008-2012.

Izvor: Autor, na osnovu zvaničnih finansijskih izveštaja 
potkrepljujemo rastom prihoda u 2011. i 2012. godini. Zaključak je da su analizirana (velika) preduzeća bila uključena u mere Vlade i da su ispunila sve neophodne uslove propisane Zakonom i knjižila uvećane prihode. $\mathrm{Na}$ ovaj način se očekivalo da će se amortizovati negativni efekti krize na teret budžeta Republike Srbije.

Sličan zaključak možemo da izvedemo ukoliko analiziramo i dinamiku nivoa obrtnih sredstava kod analiziranih privrednih društava (Grafikon 2). Naime, da bi se uvećani obim poslova realizovao, privredna društva su morala da angažuju veći obim obrtnih sredstava.

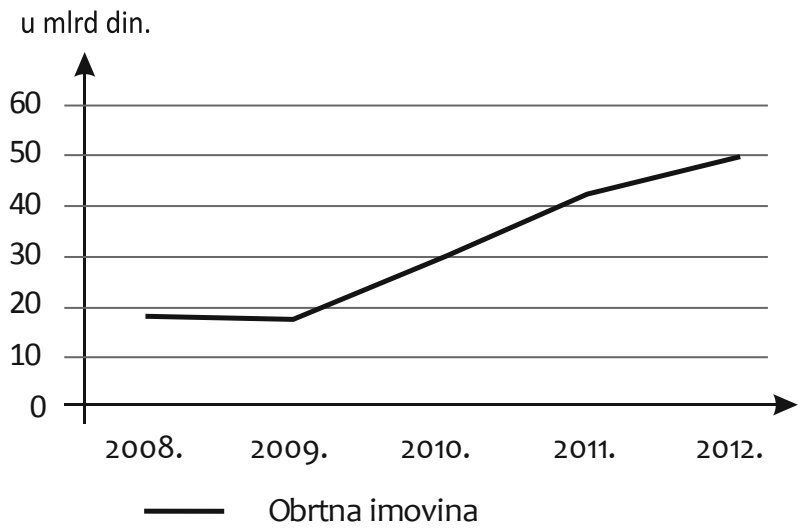

Grafikon 2 Kretanje nivoa obrtne imovine u uzorku za period 2008-2012.

Izvor: Autor, na osnovu zvaničnih finansijskih izveštaja

Međutim, ukoliko se analizira bilansna pozicija kretanja stalne imovine, može se zaključiti da su mere iz 2010. godine bile kratkoročnog karaktera. Naime, sa Grafikona 3 može se videti da nakon rasta obima stalne imovine do 2011. godine dolazi do smanjenja ove pozicije u uzorku za 2012. godinu.

Interesantno je da je smanjenje nivoa stalne imovine evidentirano kod 7 od 10 analiziranih privrednih društava. Ovo upućuje na zaključak da se nešto ozbiljnije desilo u njihovom poslovanju. Analiza rashoda finansiranja $u$ posmatranom periodu daje odgovor na postavljeno pitanje (Grafikon 4).

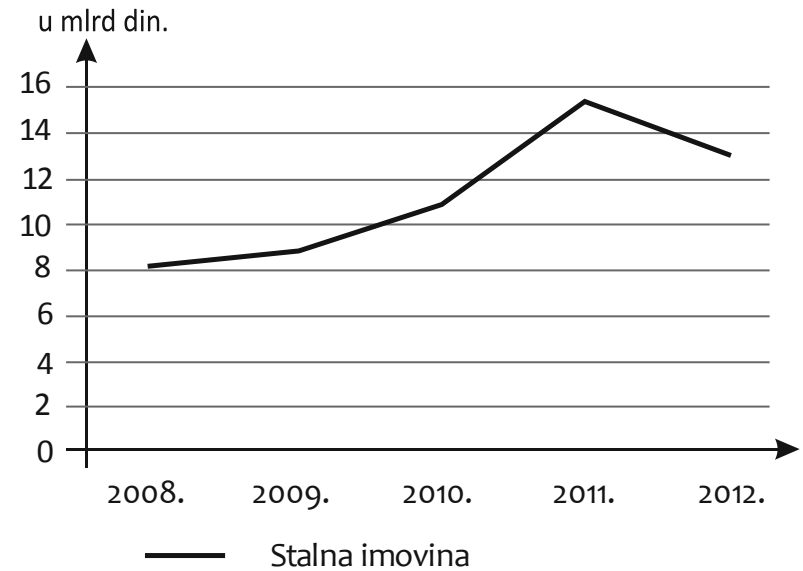

Grafikon 3 Kretanje nivoa stalne imovine u uzorku za period 2008-2012.

Izvor: Autor, na osnovu zvaničnih finansijskih izveštaja

Sa Grafikona 4 može se zaključiti da se građevinski sektor intenzivno zaduživao kako bi ispoštovao obaveze za ugovorene poslove. Međutim, ono što je izostalo jeste blagovremeno plaćanje države za preuzete obaveze. Iz razgovora sa menadžerima analiziranih kompanija ispostavilo se da država nije ispoštovala rokove plaćanja, dok su izvođači radova morali da poštuju svoje finansijske obaveze za uvećani

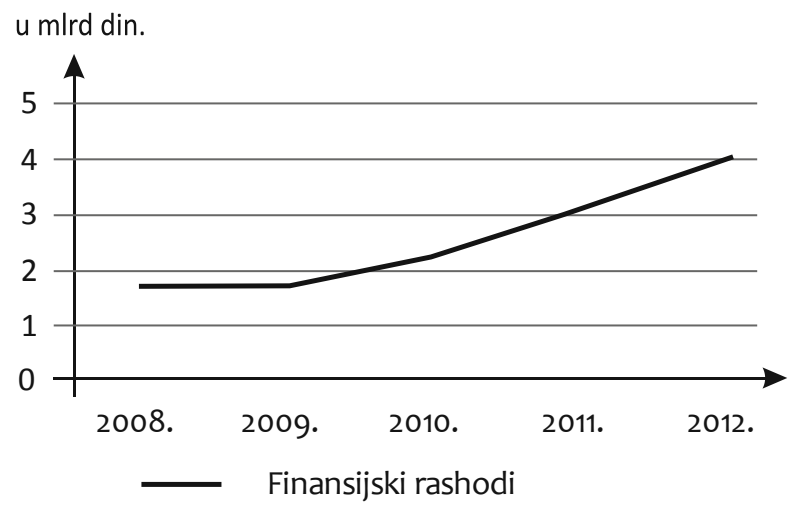

Grafikon 4 Kretanje nivoa finansijskih rashoda u uzorku za period 2008-2012.

Izvor: Autor, na osnovu zvaničnih finansijskih izveštaja 
obim poslova, koji su dobili od strane države. Sve ovo je vodilo ka povećanju udela obaveza u finansiranju, što potvrđuje Grafikon 5.

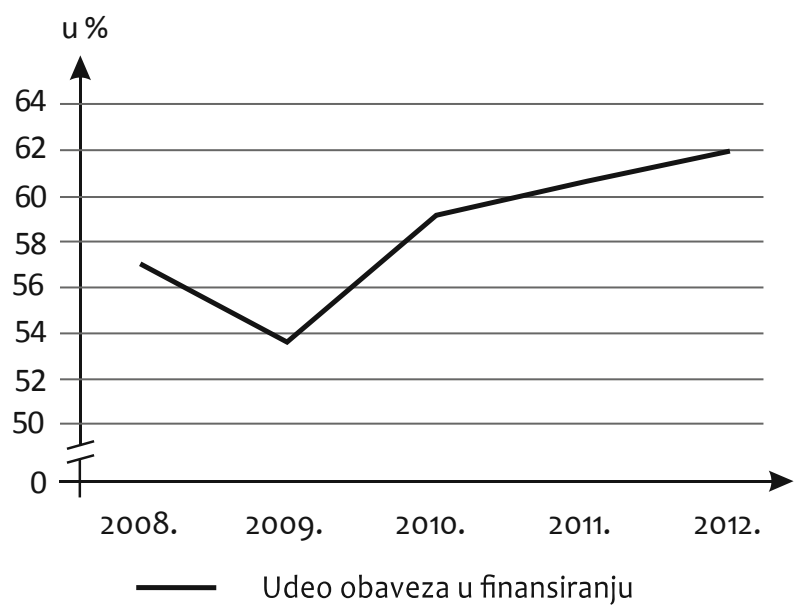

Grafikon 5 Kretanje udela obaveza u finansiranju u uzorku za period 2008-2012.

Izvor: Autor, na osnovu zvaničnih finansijskih izveštaja

Udeo obaveza u finansiranju građevinskih preduzeća u RS postepeno se smanjivao tokom 2008. i 2009. godine. Ovo iz razloga što je $u$ tom periodu bio prisutan investicioni bum $\mathrm{u}$ oblasti stanogradnje, pa su se građevinske firme polako razduživale. Treba podsetiti da je do 2008. u RS postojao tzv. „mehur cena” gotovih stanova u Beogradu, koji je bio rezultat visoke tražnje na nerealnim osnovama. Dobra alternativa za držanje gotovog novca bila je kupovina stana $\mathrm{u}$ Beogradu. Međutim, sa intenziviranjem ekonomske krize i njenim prelivanjem $u$ RS, stanje u građevinskom sektoru se znatno pogoršalo. To je imalo za posledicu enormni rast udela obaveza $u$ finansiranju, tačnije, većem zaduživanju građevinskog sektora. Pomenuta dešavanja imala su i svoje reperkusije na pokazatelje likvidnosti i obrta.
ANALIZA POKAZATELJA LIKVIDNOSTI GRAĐEVINSKOG SEKTORA U RS OD 2008. DO 2012.

Da li su efekti krize i mera Vlade imali svoje reperkusije na likvidnost ovog sektora vidimo na bazi analize koeficijenta tekuće likvidnosti. Za svaku kompaniju u uzorku, za vremenski okvir analize, izračunat je pokazatelj koeficijet tekuće likvidnosti i, proporcionalno ekonomskoj snazi kompanije (poslovni prihod) izračunat je za uzorak kao celinu. Rezultati analize prikazani su na Grafikonu 6.

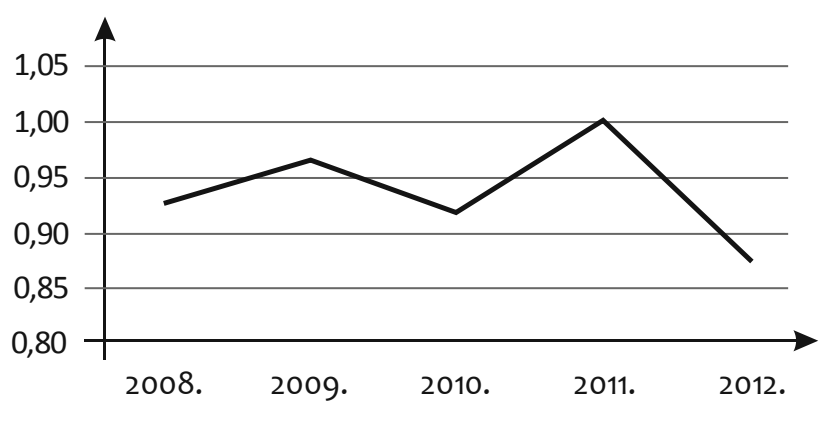

Grafikon 6 Kretanje koeficijenta tekuće likvidnosti u uzorku za period 2008-2012.

Izvor: Autor, na osnovu zvaničnih finansijskih izveštaja

Analiza je pokazala da je 2008. godine jedan dinar kratkoročnih obaveza u građevinskom sektoru u RS bio pokriven sa 0,93 dinara obrtnih sredstava. Međutim, kraj 2012. godine je pokazao da je 0,87 dinara obrtnih sredstava pokrivalo 1 dinar kratkoročnih obaveza. Kako je minimalni poželjni nivo ovog pokazatelja 1, vidi se da je likvidnost građevinskog sektora u RS na početku 2013. godine ozbiljno ugrožena. Primera radi, prema podacima APR-a, za privredu RS i kompletan građevinski sektor u Srbiji ovaj pokazatelj u 2012. godini iznosio je 1,01, odnosno 0,9 . Na ovaj način potvrđena je reprezentativnost uzorka i primenjena metodologija, ali i činjenica da je građevinski sektor 
manje likvidan $\mathrm{u}$ analiziranom periodu $\mathrm{u}$ odnosu na prosečnu likvidnost privrednih društava u RS.

Do sličnog zaključka možemo doći i ako analiziramo koeficijent naplate potraživanja (Grafikon 7).

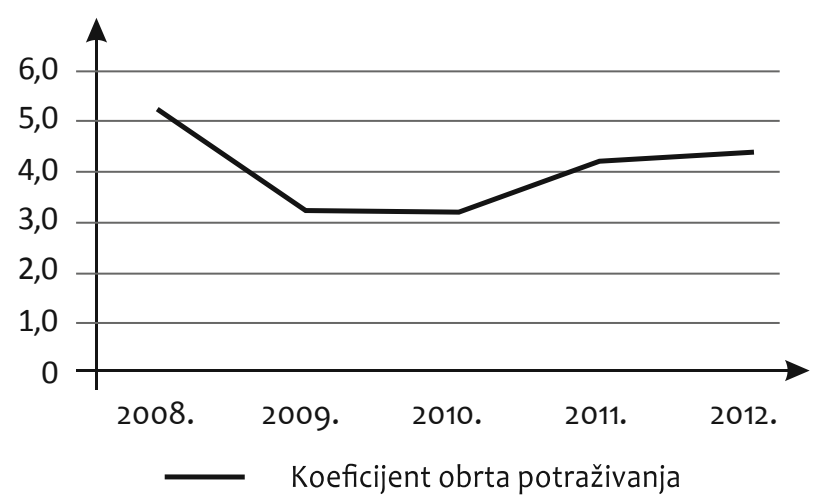

Grafikon 7 Kretanje koeficijenta obrta potraživanja u uzorku za period 2008-2012.

Izvor: Autor, na osnovu zvaničnih finansijskih izveštaja

Analiza koeficijenta naplate potraživanja na uzorku pokazuje da je u 2008. godini građevinski sektor naplaćivao svoja potraživanja u proseku za 68 dana. U 2012. godini, naplata potraživanja je u proseku realizovana za 83 dana. Interesantno je da je u 2009. i 2010. godini vrednost ovog pokazatelja bila 3,14, odnosno 3,16. Drugim rečima, bilo je potrebno skoro 114 dana da bi se naplatila potraživanja. Tako da je ova činjenica $u$ tim godinama uslovila intervenciju Vlade sa Zakonom o podsticaju, ali po prvim analizama efekti su bili kratkog daha. Primera radi, za RS (privredna društva koja predaju finansijske izveštaje APR-u), prosečan broj dana za napatu potraživanja u 2012. godini iznosio je 78 dana, dok je za sva preduzeća iz celokupne građevinske industrije u RS taj period bio 109 dana. Ovaj podatak potvrđuje da je analizirani uzorak u potpunosti reprezentativan i da opisuje pravu sliku u ovom sektoru u RS. Pitanje koje se nameće jeste kakvi su efekti na ključne pokazatelje uspešnosti poslovanja privrednih društava u oblasti građevine u Srbiji u analiziranom periodu.

\section{ANALIZA POKAZATELJA USPEŠNOSTI POSLOVANJA GRAĐEVINSKOG SEKTORA U RS OD 2008. DO 2012.}

Analizu uspešnosti poslovanja građevinskog sektora u RS posmatramo kroz tri osnovna ekonomska pokazatelja. To su: poslovna dobit, ekonomičnost i prinos na aktivu. Za svako privredno društvo iz uzorka u posmatranom periodu izračunata je vrednost pomenutih pokazatelja i na osnovu ekonomske snage svakog privrednog društva izračunat je pokazatelj za uzorak kao celinu. Kriterijum za ekonomsku snagu bilo je učešće $u$ realizovanom prihodu.

Poslovna dobit (EBITDA - Earnings Before Interest, Taxes, Depreciation and Amortization) predstavlja zaradu privrednog društva, ali bez uključivanja poreza, kamata, deprecijacije i amortizacije u kalkulaciju dobiti. Mnogi EBITDA nazivaju zaradom pre svih loših stvari i koristi se za analizu i poređenje profitabilnosti između različitih privrednih društva ili grana privrede. Dodatni razlog tome leži i u činjenici da obračun ovog pokazatelja isključuje efekte finansiranja i individualnh računovodstvenih odluka svakog privrednog subjekta. Ovaj pokazatelj apostrofira sposobnost privrednog društva da ostvaruje dobit samo iz osnovne delatnosti. Analiza poslovne dobiti (EBITDA) potvrđuje ono o čemu smo do sada diskutovali. Od 2008. do 2010. godine evidentiran je pad poslovne dobiti. Mere Vlade iz 2010. godine dale su kratkoročna poboljšanja kada je u 2011. evidentiran rast vrednosti ovog pokazatelja, ali je u 2012. njegova vrednost umanjena. Iz razgovora sa menadžerima analiziranih preduzeća, zaključuje se da je uzrok ovome rast troškova poslovanja, naročito, finansijskih rashoda i odustajanje od poslova koje naručuje država, jer nije bila dobar "platiša” (Grafikon 8).

Ekonomičnost, kao odnos između ukupnih prihoda i rashoda, jeste veoma važan pokazatelj ekonomske uspešnosti poslovanja. Iako je minimalna poželjna vrednost ovog pokazatelja jedan, istraživanje na uzorku je pokazalo da je vrednost ovog pokazatelja ispod jedinice (Grafikon 9). Ovo pokazuje da sektor izgradnje stambenih i nestambenih objekata ima slabu uspešnost $u$ poslovanju. Primera radi za RS (privredna društva koja predaju finansijske izveštaje 


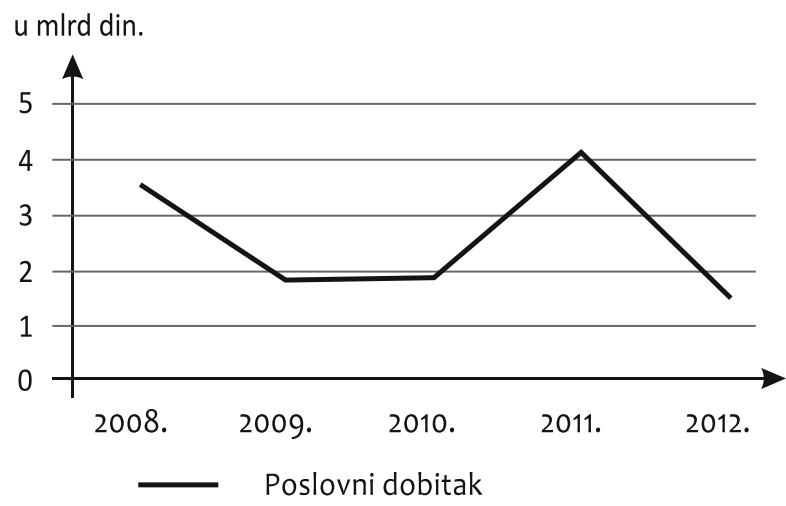

Grafikon 8 Kretanje poslovne dobiti u uzorku za period 2008-2012.

Izvor: Autor, na osnovu zvaničnih finansijskih izveštaja

APR-u), vrednost ovog pokazatelja u 2012. godini bila je 1,01, dok je za celukupnu građevinsku delatnost Srbije iznosila 0,9. Ovo je samo potvrda da je uzorak $\mathrm{u}$ ovoj analizi reprezentativan i da pokazuje aktuelnu situaciju u građevinskom sektoru RS. Analiza uzorka pokazuje permanentno smanjenje vrednosti ovog pokazatelja od 2010. godine do danas. Situacija je posebno alarmantna za 2012. godinu, kada je vrednost ukupnih prihoda mogla da pokrije samo $76 \%$ ukupnih rashoda $\mathrm{u}$ analiziranom uzorku.

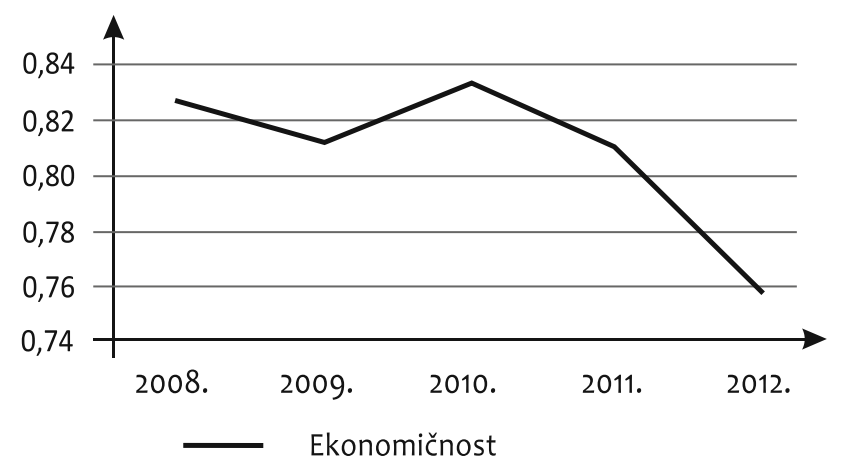

Grafikon 9 Kretanje ekonomičnosti u uzorku za period 2008-2012.

Izvor: Autor, na osnovu zvaničnih finansijskih izveštaja
ROA (Return On Assets) ili stopa prinosa na imovinu pokazuje kakva je zarađivačka sposobnost privrednog društva. Na analiziranom uzorku vidimo da je vrednost ovog pokazatelja $u$ intenzivnom padu, naročito u 2012. godini, kada jedno od najvećih privrednih društava u uzorku ima potpuno negativnu neto dobit. Ovo pokazuje da angažovana imovina od strane privrednih društava iz oblasti građevine ima skromnu zarađivačku sposobnost. Taj prinos je bio $6 \%$ u 2008. godini i od tada se smanjuje (Grafikon 10).

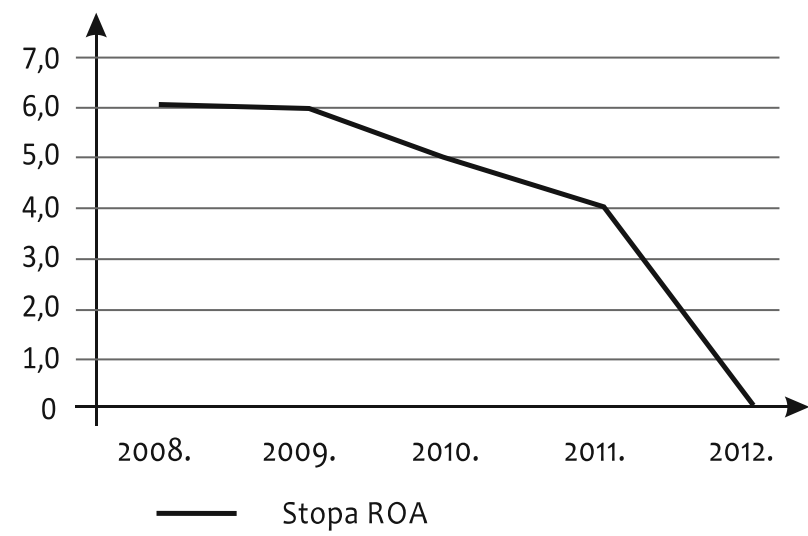

Grafikon 10 Kretanje ROA u \% u uzorku za period 2008-2012.

Izvor: Autor, na osnovu zvaničnih finansijskih izveštaja

$\mathrm{U}$ nameri da proverimo reprezentativnost uzorka, analizom podataka iz APR-a utvrdili smo da je za 2012. godinu za celukupnu građevinsku industriju RS vrednost ovog pokazatelja bila $-2,34 \%$. Ovo je još jednom potvrdilo tezu da je građevinska delatnost u RS u ozbiljnoj krizi i da, u proseku, na jedan dinar imovine angažovane $\mathrm{u}$ ovaj sektor realizuje se, $\mathrm{u}$ proseku, gubitak od 0,023 dinara. Poređenja radi, za RS kao celinu (sva preduzeća koja predaju finansijske izveštaje) vrednost ovog pokazatelja je 0,19\%. Drugim rečima, prosečno srpsko preduzeće u RS na jedan dinar imovine generiše neto dobit od 0,0019 dinara, što je izuzetno niska vrednost ovog pokazatelja. Građevinski sektor, kao deo te privrede, videli smo, beleži još lošije rezultate. 
Ova analiza je pokazala da su, kada je u pitanju građevinsi sektor $u$ RS, mere državne intervencije dale kratkoročne rezultate. Takođe, uočljivo je da su mere imale elemente klasičnog državnog neuspeha. Nije mali broj istraživačkih radova u RS koji ukazuje na tu činjenicu. Naime, „,analiza državnih neuspeha, najpre na teorijsko-metodološkom nivou, a, zatim, i iz ugla funkcionisanja domaće privrede, nosiocima ekonomske politike treba da posluži kao relevantan izvor informacija za vođenje ekonomske politike i kreiranje instituta tržišne privrede" (Petrović, 2013, 16). Ukoliko bi nosioci ekonomske politike u RS bili svesni ovih nedostataka, stvorili bi se uslovi za donošenje adekvatnih mera na osnovu kojih bi se sagledala efikasnost subvencioniranih preduzeća i efikasnost konkretnih državnih aktivnosti. Možda su neka rešenja vezana za javno privatna partnerstva $u$ ovoj oblasti dobra osnova za razmišljanje u narednom periodu (Suhaiza, 2013, 98).

\section{ZAKLJUČAK}

Analiza poslovanja građevinskog sektora u RS tokom proteklih pet godina pokazala je da ovaj sektor privređivanja ima ozbiljne probleme. Nedvosmisleno je pokazano da su ti problemi posledica nekoliko faktora. Prvi je loš institucionalni ambijent za bavljenje ovim sektorom privređivanja, a koji se ogleda $u$ nedorečenim zakonskim rešenjima koja su, umesto sigurnosti, za rezultat imala pravnu nesigurnost. Ovakav institucionalni okvir jeste odlično tlo za razvoj korupcije, kao najvećeg sistemskog problema srpskog društva. Drugi, neadekvatni izvori finansiranja za ovu veoma specifičnu granu privrede i treći neadekvatan odgovor države u stimulisanju ovog sektora privrede u uslovima aktuelne ekonomske krize. Sprovedeno istraživanje je potvrdilo da su navedeni faktori doprineli pogoršanju likvidnosti grđevinske delatnosti i to za $10 \%$ ispod ionako niskog nivoa likvidnosti privrednih društava $\mathrm{u} R \mathrm{R}$, a da je neadekvatno koncipirana pomoć ovom sektoru privrede uticala na to da "miljenici” prethodne vlasti imaju neadekvatne pokazatelje uspešnosti poslovanja, naročito $u$ segmentu prinosa na angažovanu imovinu, koja je za 2012. imala negativnu vrednost.
Sveukupno istraživanje je potvrdilo polaznu hipotezu da su efekti državne intervencije bili kratkotrajnog karaktera i da su u jednom segmentu uzrok lošeg stanja u ovom sektoru privrede RS.

$\mathrm{Na}$ ovaj način istraživanje je pokazalo da za građevinsku industriju treba koncipirati sistemske mere, kako bi se ovaj sektor izveo na put oporavka. Sistemski pristup podrazumeva da osim neposrednih finansijski podsticaja, mnogo dalekosežnije efekte mogu imati mere $u$ promeni institucionalnog ambijenta u kome posluje ovaj sektor.

\section{REFERENCE}

Isailović, I. (2012). Propast građevinske industrije. Profit, decembar 2011 / januar 2012, 12-13.

Leković, V. (2001). Korelacija tržišne institucionalizacije i tranzicionih procesa. Ekonomski horizonti, 1-2, 31-42.

Lewis, A. (1963). Economic Development with Unlimited Supplies of Labor: The Economics of Underdevelopment. New York.

Lewis, A. (1966). Development Planing. London, UK: G. Allen.

Mladenović, I. i Cvetanović, S. (2011). Kapital u teoriji rasta $i$ razvoja, Niš, Ekonomski fakultet Univerziteta u Nišu.

Mladenović, I., Ćuzović, S., \& Sokolov, S. (2012). Business performances of the Serbian trade sector in conditions of internationalization. Industrija, 40(4), 41-62.

Mladenović, I., Stanković, Lj., Đukić, S., i Popović, A. (2011). Unapređenje poslovne konkurentnosti preduzeća zasnovano na inovacijama. Ekonomske teme, 4, 559-580.

Oladinrin, T., Ogunsemi, D., \& Aje, I. (2012). Role of Construction Sector in Economic Growth: Empirical Evidence from Nigeria. FUTY Journal of the Environment, 7(1), 50-60.

Patricia, M. H. (1974). Economic Theory and the Construction Industry. MacMillan Press.

Petrović, D. (2013). Ključni teorijski i praktični aspekti državnih neuspeha u savremenoj ekonomiji. Ekonomski horizonti, 15(2), 149-161.

Privredna komora Srbije. Privreda Srbije. dostupno na http:// www.pks.rs/PrivredaSrbije.aspx?id=7\&p=2\&

Samuelson, P., \& Nordahaus, W. (1992). Ekonomija. Zagreb, Hrvatska: Mate. 
Službeni glasnik RS, 45/2010.

Suhaiza, I. (2013). Factors attracting the use of public private partnership in Malaysia. Journal of Construction in Developing Countries, 18(1), 95-108.

The International Bank for Reconstruction and Development / The World Bank, Doing Business 2013, dostupno na http:// www.doingbusiness.org/ /media/giawb/doing\%20business/ documents/profiles/country/SRB.pdf

Uredba o merama podrške građevinskoj industriji kroz dugoročno stambeno kreditiranje u 2012.

Zvanični finansijski izveštaji od 2008. do 2012. A.D. „Putevi Užice", Užice.

Zvanični finansijski izveštaji od 2008. do 2012. „Građevinska Direkcija Srbije" d.o.o Beograd.

Zvanični finansijski izveštaji od 2008. do 2012. A.D. „Energoprojekt - visokogradnja”, Beograd.
Zvanični finansijski izveštaji od 2008. do 2012. „Deneza M Inženjering" d.o.o, Beograd.

Zvanični finansijski izveštaji od 2008. do 2012. „Inter-Kop” d.o.o., Šabac.

Zvanični finansijski izveštaji od 2008. do 2012. „Energo group” d.o.o., Beograd.

Zvanični finansijski izveštaji od 2008. do 2012. „Tehnogradnja” d.o.o., Kruševac.

Zvanični finansijski izveštaji od 2008. do 2012. „PMC Inženjering" d.o.o. Beograd.

Zvanični finansijski izveštaji od 2008. do 2012. „Gradina” d.o.o., Beograd.

Zvanični finansijski izveštaji od 2008. do 2012. „AG Strabag”, Beograd.

Primljeno 6. novembra 2013,

nakon revizije,

prihvaćeno za publikovanje 17. decembra 2013.

Igor Mladenović je vanredni profesor na Ekonomskom fakultetu Univerziteta u Nišu, na nastavnim predmetima Makroekonomija i Teorija i politika privrednog razvoja. Doktorirao je u oblasti uloga institucionalnih investitora $\mathrm{u}$ finansiranju privrednog razvoja, na Ekonomskom fakultetu Univerziteta u Nišu. 


\title{
THE CONSTRUCTION INDUSTRY IN FUNCTION OF THE RECOVERY OF THE REPUBLIC OF SERBIA ECONOMY
}

\author{
Igor Mladenovic* \\ Faculty of Economics, University of Nis, Nis, Serbia
}

\begin{abstract}
The current economic crisis has affected the level of the economic activity in many sectors of the economy. Among theorists and practitioners, the construction industry, followed by all the other industries, is increasingly said to be facing a serious crisis and to encourage its recovery of the overall economy of the Republic of Serbia. For this, the construction industry is said to be able to bear half of the economic growth of Serbia. However, taking into account the above-mentioned positions, the question is what the effects of the economic crisis on this economic sector are and what the effects of the measures imposed by the previous government of the Republic of Serbia regarding this sector were. Searching for answers to this question can to a great extent profile the answer of the current government regarding the solving of the problems in the Serbian construction industry.
\end{abstract}

Keywords: economic crisis, institutional environment, state subsidies, construction sector

JEL Classification: G01, E29, E29, D22 